\title{
The Unseen Part of Modernisation
}

\author{
Karthik D Yadav* \\ Department of oral medicine and radiology, The oxford dental college and research center, India
}

Submission: July 20, 2018; Published: July 26, 2018

*Corresponding author: : Karthik D Yadav, Department of oral medicine and radiology, The oxford dental college and research center, India, Tel: +919902824646; Email: karthikyadavd@gmail.com

\section{Short Communication}

Technology reflects the greatest achievements of mankind. However, like a coin there are two aspects of the same, in which one part has contributed to the increased sedentary lifestyle across different age groups and socioeconomic levels. The flip side has widespread fitness technology such as smartphone applications and wearable technologies which offers innovative solutions to increase and promote physical activity. At present, not less than 6.8 billion people worldwide use mobile phones. A 2013 study showed that there are over 40,000 health and fitness apps currently available to the public, and over half of smartphone users report having downloaded such applications $[1,2]$.

An estimated 3.2 million deaths globally have been attributed to physical inactivity by World Health Organization (WHO) and as the fourth leading risk factor for global mortality causing. Also the number of deaths per year increases to six million, with overweight and obesity as contributory factors [3]. Prevention is better than cure. Hence, our normal day to day activities such as walking, cycling, and sports activities which have noteworthy benefits for fitness also play a vital role in preventing obesity [4]. Walking has gained much interest in recent years as a feasible strategy for increasing physical activity. Walking is a free, low-impact way to meet the CDC recommendation of $150 \mathrm{~min}$ of moderate-intensity exercise per week. It can be done just about anywhere, at any time, and neither requires specialized equipment nor a gym membership [1].

However, the relation between the measure of physical activity and abdominal fat distribution has not been well characterized [5,6]. Some studies have definitely displayed that regular physical activity decreases the risk of diseases and reduces death rate and extend life expectancy [6-8]. Fitness technology which includes fitness trackers and smartphone applications is publicly available and provides the data regarding the amount and intensity of activity. Further technology encompasses individual fitness trackers that can stand alone or that pairs with an application that can be downloaded onto a smartphone [1]
As technology devices and services are penetrating the society into deeper levels, the need for studying their usefulness for physical activity and wellness becomes imperative. Modern technology and popularization of internet has brought a variety of applications aiming at promoting personal health and wellness available for layman, such as pedometers, heart rate monitors, and multidimensional accelometers [1]. Being physically active has its own benefits. Hence, a change of lifestyle with increased physical activities is the need of the hour. However, this does not mean that we should neglect the technology available to us. But rather it should be used to further enhance our fitness levels.

\section{References}

1. Sullivan AN, Lachman ME (2016) Behavior Change with Fitness Technology in Sedentary Adults: A Review of the Evidence for Increasing Physical Activity. Front Public Health 4: 289.

2. http://www.humankinetics.com/excerpts/excerpts/technology-can-boost-physical-activity-promotion-nbsp

3. WHO (2015) Global Strategy on Diet, Physical Activity and Health.

4. Ekelund U, Besson H, Luan J (2011) Physical activity and gain in abdominal adiposity and body weight: prospective cohort study in 288,498 men and women. American Journal of Clinical Nutrition 93(4): 826835.

5. Philipsen A (2014) Associations of Objectively Measured Physical Activity and Abdominal Fat Distribution. Medical Science and Sports Exercis 47(5): 983-989.

6. Vanhees L, Geladas N, Hansen D (2012) Importance of characteristics and modalities of physical activity and exercise in the management of cardiovascular health in individuals with cardiovascular risk factors: Recommendations from the EACPR. Part II. European Journal Preventive Cardiology 19(5): 1005-1033.

7. Wen CP, Wai JPM, Tsai MK (2001) Minimum amount of physical activity for reduced mortality and extended life expectancy: A prospective cohort study. The Lancet 378(9798): 1244-1253.

8. Tudor Locke C, Hart TL, Washington TL (2009) Expected values for pedometer-determined physical activity in older populations. International Journal of Behavioral Nutrition and Physical Activity 6: 59. 
Your next submission with Juniper Publishers will reach you the below assets

- Quality Editorial service

- Swift Peer Review

- Reprints availability

- E-prints Service

- Manuscript Podcast for convenient understanding

- Global attainment for your research

- Manuscript accessibility in different formats

( Pdf, E-pub, Full Text, Audio)

- Unceasing customer service

Track the below URL for one-step submission https://juniperpublishers.com/online-submission.php 